\title{
A Dynamic Fuzzy Approach Based on the EDAS Method for Multi-Criteria Subcontractor Evaluation
}

\author{
Mehdi Keshavarz-Ghorabaee ${ }^{1}$ (D), Maghsoud Amiri ${ }^{1}$, Edmundas Kazimieras Zavadskas ${ }^{2, *}$ (iD, \\ Zenonas Turskis $^{2}$ (D) and Jurgita Antucheviciene 2 (iD) \\ 1 Department of Industrial Management, Faculty of Management and Accounting, Allameh Tabataba'i \\ University, Tehran 1489684511, Iran; m.keshavarz_gh@ieee.org (M.K.-G.); amiri@atu.ac.ir (M.A.) \\ 2 Department of Construction Management and Real Estate, Vilnius Gediminas Technical University, \\ Sauletekio al. 11, LT-10223 Vilnius, Lithuania; zenonas.turskis@vgtu.lt (Z.T.); \\ jurgita.antucheviciene@vgtu.lt (J.A.) \\ * Correspondence: edmundas.zavadskas@vgtu.lt; Tel.: +370-5-274-4910
}

Received: 2 March 2018; Accepted: 17 March 2018; Published: 19 March 2018

\begin{abstract}
Selection of appropriate subcontractors for outsourcing is very important for the success of construction projects. This can improve the overall quality of projects and promote the qualification and reputation of the main contractors. The evaluation of subcontractors can be made by some experts or decision-makers with respect to some criteria. If this process is done in different time periods, it can be defined as a dynamic multi-criteria group decision-making (MCGDM) problem. In this study, we propose a new fuzzy dynamic MCGDM approach based on the EDAS (Evaluation based on Distance from Average Solution) method for subcontractor evaluation. In the procedure of the proposed approach, the sets of alternatives, criteria and decision-makers can be changed at different time periods. Also, the proposed approach gives more weight to newer decision information for aggregating the overall performance of alternatives. A numerical example is used to illustrate the proposed approach and show the application of it in subcontractor evaluation. The results demonstrate that the proposed approach is efficient and useful in real-world decision-making problems.
\end{abstract}

Keywords: multi-criteria decision-making; group decision-making; subcontractor evaluation; MCDM; MADM; fuzzy sets; fuzzy EDAS

\section{Introduction}

Subcontracting is one of the most important characteristics of the construction industry. In many construction projects, the main contractor has usually the role of project coordinator, and a high percentage of work is done by subcontractors [1,2]. The completion time of a construction project (project delivery) and the reputation of the main contractor are heavily dependent on cooperation between a subcontractor and its main contractor [3]. Therefore, the performance of subcontractors could have a significant effect on the success of construction projects. Because of the increasing use of subcontracting in the construction industry, evaluation of subcontractors can be considered as an essential problem for the main contractors.

The subcontractor evaluation process (SEP) usually involves several alternatives (subcontractors), multiple criteria and a group of decision-makers (experts). Thus, we can consider this process as a multi-criteria group decision-making (MCGDM) problem [4]. Moreover, the main contractor generally needs to evaluate its subcontractors in multiple periods of time. This process makes the SEP into a dynamic MCGDM problem. In a dynamic MCGDM problem, the set of alternatives, criteria and decision-makers can be changed in different time periods [5]. Thus, we can make the evaluation process with a high degree of flexibility. In addition, the assessments of experts can be made under 
uncertainty in the SEP. The fuzzy sets theory is a useful tool to deal with the uncertainty of evaluation process [6-11].

There have been some studies on the problems related to the SEP and multi-criteria decision-making (MCDM) methods under certain and uncertain environments. Cheng, et al. [12] proposed a hierarchical structure for the target and factors for evaluation of subcontractors, and used the analytic hierarchy process (AHP) to select an appropriate subcontractor. Kargi and Öztürk [13] used the AHP method and the Expert Choice software for evaluation of subcontractors in a Turkish company. Yayla, et al. [14] presented a case study for selection of the optimal subcontractor in a Turkish textile firm. They used generalized Choquet integral methodology and a hierarchical decision model to solve the selection problem. $\mathrm{Ng}$ and Skitmore [15] proposed an approach based on the balanced scorecard methodology for evaluation of subcontractor and performed a questionnaire survey administered in Hong Kong. Abbasianjahromi, et al. [16] developed a model for subcontractor evaluation based on the fuzzy preference selection index. In their model, the weighting criteria phase is eliminated in the evaluation process of subcontractors. Shahvand, et al. [17] developed a multi-criteria fuzzy expert system for supplier and subcontractor evaluation in the construction industry and used it in three companies. Polat [2] presented an integrated MCDM approach based on AHP and preference ranking organization method for enrichment evaluations (PROMETHEE), and applied it to the subcontractor selection problem. Ulubeyli and Kazaz [18] proposed a fuzzy multi-criteria decision-making approach, called CoSMo (Construction Subcontractor selection Model), for evaluation of subcontractors in the construction projects. Abbasianjahromi, et al. [19] developed a new model to allocate the tasks of a construction project to some subcontractors for optimization of the portfolio of subcontractors and main contractor. Polat, et al. [20] proposed an integrated approach based on the AHP and Evidential Reasoning (ER) methods. They used AHP and ER to find the criteria weights for evaluation of subcontractors and rank the alternatives, respectively.

Dynamic MCDM approaches have been used by researchers in several fields. Campanella and Ribeiro [21] introduced a flexible framework for dynamic MCDM that can be used in many dynamic decision processes, and applied it to a small helicopter landing problem. Wei [22] utilized grey relational analysis (GRA) to develop a dynamic MCDM approach. Chen and Li [23] proposed a dynamic MCDM method based on triangular intuitionistic fuzzy numbers. Wang, et al. [24] presented a three-dimensional grey interval relational degree approach for dynamic multi-criteria decision-making problems. They applied the presented approach to the investment decision-making problems. Junhua, et al. [25] developed a dynamic stochastic MCDM approach based on conjoint analysis and prospect theory. Li, et al. [26] proposed a dynamic fuzzy MCDM method using a mathematical programming model and fuzzy technique for order preference by similarity to ideal solution (TOPSIS). Yan, et al. [27] presented a dynamic grey target MCDM method using interval numbers and based on the status of alternatives. Liu, et al. [28] proposed a dynamic fuzzy framework based on GRA and used it for evaluation of emergency treatment technology. Yan, et al. [29] developed a new dynamic MCDM approach with three-parameter grey numbers. In their approach, not only the attribute values of alternatives at all periods are aggregated, but also changes of these values between the adjacent periods are considered.

The EDAS (Evaluation based on Distance from Average Solution) method is a new and efficient method which introduced by Keshavarz Ghorabaee, et al. [30] and extended for using in the fuzzy environment [31]. The evaluation process in the EDAS method is made based on the distances of alternative from an average solution. Two types of distances (positive and negative) are defined for alternatives in this method, and the utility of alternatives is determined based on these distances. This method has been developed for using in different uncertain environments such as intuitionistic fuzzy sets [32], interval-valued neutrosophic sets [33], interval-valued fuzzy soft sets [34], neutrosophic soft sets [35], interval grey numbers [36] and interval type-2 fuzzy sets [37]. Also, the EDAS method has been applied to some real-world MCDM problems such as life cycle and sustainability assessment [38], 
supplier selection [39], architectural shape of the buildings [40], cultural heritage structures [41], quality assurance [42], evaluation in logistics [43,44] and stairs shape assessment [45].

In this study, we propose a new dynamic fuzzy MCGDM approach based on the EDAS method for evaluation of subcontractors. The main advantage of the proposed approach is its flexibility so that we can define different sets of alternatives, criteria and decision-makers in different time periods and make the evaluation in a fuzzy environment. Because of the importance of new information, we use a function that gives greater weights to newer time periods for aggregating the performance score of each alternative. A numerical example of subcontractor evaluation is presented to illustrate the proposed approach and show the efficiency of it.

The rest of this article is organized as follows. Section 2 describes the methodology. In this section, first, we present concepts and some definitions related to the fuzzy sets theory and the arithmetic operations of the fuzzy numbers, then the steps and flowchart of the proposed approach is depicted in detail. In Section 3, a numerical example is used to show the application of the proposed approach in subcontractor evaluation. Conclusions are briefly discussed in Section 4.

\section{Methodology}

In this section, we first present some concepts and definitions about the fuzzy sets theory, and then an extended dynamic fuzzy EDAS is described for multi-criteria group decision-making.

\subsection{Concepts and Definitions of Fuzzy Sets}

To deal with the uncertainty of information in real-world problems, the fuzzy sets theory was developed by Zadeh [46]. The membership of elements in a fuzzy set is described by means of a membership function with a range in $[0,1]$. Therefore, fuzzy sets generalize classical sets in which the membership of elements has a two-valued condition (zero or one). The fuzzy set theory has been applied to many problems in different fields of science and engineering. To describe this theory, some definitions are presented as follows:

Definition 1. Let denote by $X$ a universal set. Then a fuzzy set $\widetilde{G}$ can be defined by a membership function $\mu_{\widetilde{G}}(x)$ as follows [47]:

$$
\widetilde{G}=\left\{\left(x, \mu_{\widetilde{G}}(x)\right) \mid x \in X\right\}
$$

In the above equation, $x$ denotes the elements belong to $X$, and $\mu_{\widetilde{G}}(x): X \rightarrow[0,1]$.

Definition 2. A fuzzy number can be defined as a special case of a fuzzy set which is convex and normal [48].

Definition 3. If the membership function of a fuzzy number $\widetilde{G}$ is defined by the following equation then we can call it a triangular fuzzy number [49]:

$$
\mu_{\widetilde{G}}(x)=\left\{\begin{array}{lr}
\left(x-g_{1}\right) /\left(g_{2}-g_{1}\right), & g_{1} \leq x \leq g_{2} \\
\left(g_{3}-x\right) /\left(g_{3}-g_{2}\right), & g_{2} \leq x \leq g_{3} \\
0, & \text { otherwise }
\end{array}\right.
$$

A triplet $\widetilde{G}=\left(g_{1}, g_{2}, g_{3}\right)$ can also be used to define this fuzzy number. Figure 1 represents an example of triangular fuzzy numbers.

In this study, we use the triangular fuzzy sets due to their simplicity of presentation and computation. However, the other types of fuzzy numbers such as trapezoidal fuzzy number can also be used in the methodology proposed in the following sub-section. 


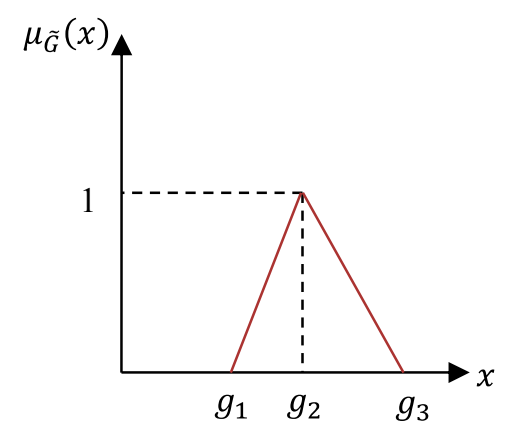

Figure 1. A triangular fuzzy number.

Definition 4. Let us define $\widetilde{G}=\left(g_{1}, g_{2}, g_{3}\right)$ and $\widetilde{H}=\left(h_{1}, h_{2}, h_{3}\right)$ as two triangular fuzzy numbers which are also positive (i.e., $g_{1} \geq 0$ and $h_{1} \geq 0$ ), and suppose that $q$ is a crisp number. In the following equations, the arithmetic operations of these fuzzy numbers are presented [49]:

- Addition:

$$
\begin{gathered}
\widetilde{G} \oplus \widetilde{H}=\left(g_{1}+h_{1}, g_{2}+h_{2}, g_{3}+h_{3}\right) \\
\widetilde{G}+q=\left(g_{1}+q, g_{2}+q, g_{3}+q\right)
\end{gathered}
$$

- Subtraction:

$$
\begin{gathered}
\widetilde{G} \ominus \widetilde{H}=\left(g_{1}-h_{3}, g_{2}-h_{2}, g_{3}-h_{1}\right) \\
\widetilde{G}-q=\left(g_{1}-q, g_{2}-q, g_{3}-q\right)
\end{gathered}
$$

- Multiplication:

$$
\begin{gathered}
\widetilde{G} \otimes \widetilde{H}=\left(g_{1} \times h_{1}, g_{2} \times h_{2}, g_{3} \times h_{3}\right) \\
\widetilde{G} \times q=\left\{\begin{array}{l}
\left(g_{1} \times q, g_{2} \times q, g_{3} \times q\right) \text { if } q \geq 0 \\
\left(g_{3} \times q, g_{2} \times q, g_{1} \times q\right) \text { if } q<0
\end{array}\right.
\end{gathered}
$$

- Division:

$$
\begin{gathered}
\widetilde{G} \oslash \widetilde{H}=\left(g_{1} / h_{3}, g_{2} / h_{2}, g_{3} / h_{1}\right) \\
\widetilde{G} / q=\left\{\begin{array}{l}
\left(g_{1} / q, g_{2} / q, g_{3} / q\right) \text { if } q>0 \\
\left(g_{3} / q, g_{2} / q, g_{1} / q\right) \text { if } q<0
\end{array}\right.
\end{gathered}
$$

Definition 5. The defuzzified or crisp value of a triangular fuzzy number $\widetilde{G}=\left(g_{1}, g_{2}, g_{3}\right)$ can be defined by the following equation [50]:

$$
\mathfrak{D}(\widetilde{G})=\frac{1}{3}\left(g_{1}+g_{2}+g_{3}\right)
$$

Definition 6. To find the maximum between a triangular fuzzy number $\widetilde{G}=\left(g_{1}, g_{2}, g_{3}\right)$ and zero, the following function can be used [31].

$$
\mathcal{S}(\widetilde{A})=\left\{\begin{array}{lll}
\widetilde{G} & \text { if } & \mathfrak{D}(\widetilde{G})>0 \\
\widetilde{0} & \text { if } & \mathfrak{D}(\widetilde{G}) \leq 0
\end{array}\right.
$$

where $\widetilde{0}=(0,0,0)$. 


\subsection{Dynamic Fuzzy EDAS}

The EDAS method is a new and efficient MCDM method introduced by Keshavarz Ghorabaee, Zavadskas, Olfat and Turskis [30], and has been extended to deal with fuzzy MCDM problems [31]. In this section, a new approach is proposed to handle dynamic fuzzy multi-criteria group decision-making based on the EDAS method, which is called dynamic fuzzy EDAS.

In a dynamic multi-criteria group decision-making, the multi-criteria evaluation process is made by multiple decision-makers in multiple periods. In each period, we have a set of alternatives that needs to be evaluated with respect to a set of criteria. Suppose that there are $T$ periods and $D M_{t}$, $C R_{t}$ and $A L_{t}$ denote the sets of decision-makers, criteria, and alternatives at period $t$, respectively. The cardinality of these sets can be defined as $\left|D M_{t}\right|=k_{t},\left|C R_{t}\right|=m_{t}$ and $\left|A L_{t}\right|=n_{t}$. In other words, we have $k_{t}$ decision-makers, $m_{t}$ criteria and $n_{t}$ alternatives at period $t$.

Step 1: Start with the first period $(t=1)$.

Step 2: Define the sets of decision-makers, criteria, and alternatives $\left(D M_{t}, C R_{t}\right.$ and $\left.A L_{t}\right)$ at period $t$.

Step 3: Determine the union of the sets of alternatives at period $t$ denoted by $A L_{t}^{T}$, where $A L_{t}^{T}=A L_{t-1}^{T} \cup A L_{t}$ and $A L_{0}^{T}=\varnothing$.

Step 4: Construct the decision-matrix and the matrix of criteria weights related to each decision-maker at period $t$ as follows:

$$
\begin{aligned}
& X_{p t}=\left[\widetilde{x}_{i j p t}\right]_{n_{t} \times m_{t}} \\
& W_{p t}=\left[\widetilde{w}_{j p t}\right]_{1 \times m_{t}}
\end{aligned}
$$

where $\widetilde{x}_{i j p t}$ denotes the rating of $i$ th alternative $\left(A_{i}\right)$ on $j$ th criterion $\left(C_{j}\right)$ given by $p$ th decision-maker, and $\widetilde{w}_{j p t}$ shows the importance or weight of $j$ th criterion given by $p$ th decision-maker $\left(1 \leq i \leq n_{t}\right.$, $1 \leq j \leq m_{t}$ and $1 \leq p \leq k_{t}$ ).

Step 5: Determine the average decision-matrix at period $t$ using the following equations:

$$
\begin{gathered}
X_{t}=\left[\widetilde{x}_{i j t}\right]_{n_{t} \times m_{t}} \\
\widetilde{x}_{i j t}=\frac{1}{k_{t}} \underset{p=1}{k_{t}} \widetilde{x}_{i j p t}
\end{gathered}
$$

where $\widetilde{x}_{i j t}$ shows the average ratings at period $t$. If the decision-makers or experts, depending on their experience and knowledge, have different importance in the process of decision-making, we can use a weighted average instead of ordinary average of Equation (16).

Step 6: Compute the average matrix of criteria weights at period $t$ presented as follows:

$$
\begin{gathered}
W_{t}=\left[\widetilde{w}_{j t}\right]_{1 \times m_{t}} \\
\widetilde{w}_{j t}=\frac{1}{k_{t}} \underset{p=1}{k_{t}} \widetilde{w}_{j p t}
\end{gathered}
$$

where $\widetilde{w}_{j t}$ denotes the average weights of criteria at period $t$. Like the previous step, we can also use a weighted average instead of ordinary average of Equation (18) if there are different weights for decision-makers.

It should be noted that if we have a problem with a hierarchical structure including some criteria and sub-criteria, we should calculate the average weights of criteria and sub-criteria first. Then the global weights of sub-criteria should be determined by multiplying the average calculated weights of them by the average weights of their upper level criterion. 
Step 7: Calculate average solutions at period $t$ using the following formula:

$$
\widetilde{g}_{j t}=\frac{1}{n_{t}} \underset{i=1}{n_{t}} \widetilde{x}_{i j t}
$$

Step 8: Let denote by $B C_{t}$ and $N C_{t}$ the sets of beneficial and non-beneficial criteria at period $t$, respectively. The values of positive and negative distances from the average solutions at each period are calculated as follows:

$$
\begin{aligned}
& \widetilde{p d}_{i j t}=\left\{\begin{array}{lll}
\frac{\mathcal{S}\left(\widetilde{x}_{i j t} \ominus \widetilde{g}_{j t}\right)}{\mathfrak{D}\left(\widetilde{g}_{j t}\right)} & \text { if } & j \in B C_{t} \\
\frac{\mathcal{S}\left(\widetilde{g}_{j t} \ominus \widetilde{x}_{i j t}\right)}{\mathfrak{D}\left(\widetilde{g}_{j t}\right)} & \text { if } & j \in N C_{t}
\end{array}\right. \\
& \widetilde{n d}_{i j t}=\left\{\begin{array}{lll}
\frac{\mathcal{S}\left(\widetilde{g}_{j t} \ominus \widetilde{x}_{i j t}\right)}{\mathfrak{D}\left(\widetilde{g}_{j t}\right)} & \text { if } & j \in B C_{t} \\
\frac{\mathcal{S}\left(\widetilde{x}_{i j t} \ominus \widetilde{g}_{j t}\right)}{\mathfrak{D}\left(\widetilde{g}_{j t}\right)} & \text { if } & j \in N C_{t}
\end{array}\right.
\end{aligned}
$$

where $\widetilde{p d}_{i j t}$ and $\widetilde{n d}_{i j t}$ denote the values of positive and negative distances from the average solutions at period $t$, respectively.

Step 9: Compute the weighted sum of the positive and negative distances for each alternative at period $t$ using the following equations:

$$
\begin{gathered}
\widetilde{s p}_{i t}={\underset{j=1}{j=1}}_{\substack{m_{t} \\
\widetilde{s n}_{i t}}}^{\oplus} \underset{\substack{m_{t} \\
j=1}}{\oplus}\left(\widetilde{w}_{j t} \otimes \widetilde{p d}_{i j t} \otimes \widetilde{n d}_{i j t}\right)
\end{gathered}
$$

Step 10: Calculate the normalized values of $\widetilde{s p}_{i t}$ and $\widetilde{s n}_{i t}$ as follows:

$$
\begin{gathered}
\widetilde{n p}_{i t}=\frac{\widetilde{s p}_{i t}}{\max _{l}\left(\mathfrak{D}\left(\widetilde{s p}_{l t}\right)\right)} \\
\widetilde{n n}_{i t}=1-\frac{\widetilde{s n}_{i t}}{\max _{l}\left(\mathfrak{D}\left(\widetilde{s n}_{l t}\right)\right)}
\end{gathered}
$$

Step 11: Compute the overall performance score of $i$ th alternative at period $t\left(\widetilde{U}_{i t}\right)$ by the following formula:

$$
\widetilde{U}_{i t}=\frac{1}{2}\left(\widetilde{n p}_{i t} \oplus \widetilde{n n}_{i t}\right)
$$

Step 12: Calculate the dynamic scores $\left(S_{i t}\right)$ for all alternatives which are the elements of the set $A L_{t}^{T}\left(A_{i} \in A L_{t}^{T}\right)$ by the following equation:

$$
S_{i t}=\left\{\begin{array}{lll}
\mathfrak{D}\left(\widetilde{U}_{i t}\right) & \text { if } & A_{i} \in A L_{t} \\
0 & \text { if } & A_{i} \notin A L_{t}
\end{array}\right.
$$

Step 13: Let $\rho_{t}$ denotes the weight or importance of period $t$. Compute the aggregated dynamic scores $\left(H_{i t}\right)$ of the alternatives belong to the set $A L_{t}^{T}$ as follows:

$$
H_{i t}=\left(1-\rho_{t}\right) H_{i(t-1)}+\rho_{t} S_{i t}
$$


where $H_{i 0}=0$, and if $A_{i} \notin A L_{t-1}^{T}$ then $H_{i(t-1)}=\min _{l, l \in A L_{t-1}^{T}} H_{l(t-1)}$.

Because newer information is more important in decision-making, a weight function of periods that gives greater weight to the current period should be defined. We define the following function for setting the weights of periods:

$$
\rho_{t}=\frac{t}{2 t-1}
$$

In Equation (29), the value of $\rho_{t}$ is equal to 1 for the first period $(t=1)$, and it is always greater than 0.5 .

Step 14: Increase the value of period by $1(t \leftarrow t+1)$. If $t<T$ go to Step 2, otherwise continue.

Step 15: Evaluate the alternatives according to the values of aggregated dynamic scores $\left(H_{i t}\right)$. The higher values of $H_{i t}$ get the better alternatives.

To make the proposed approach clear, its procedure is depicted by a flowchart in Figure 2.

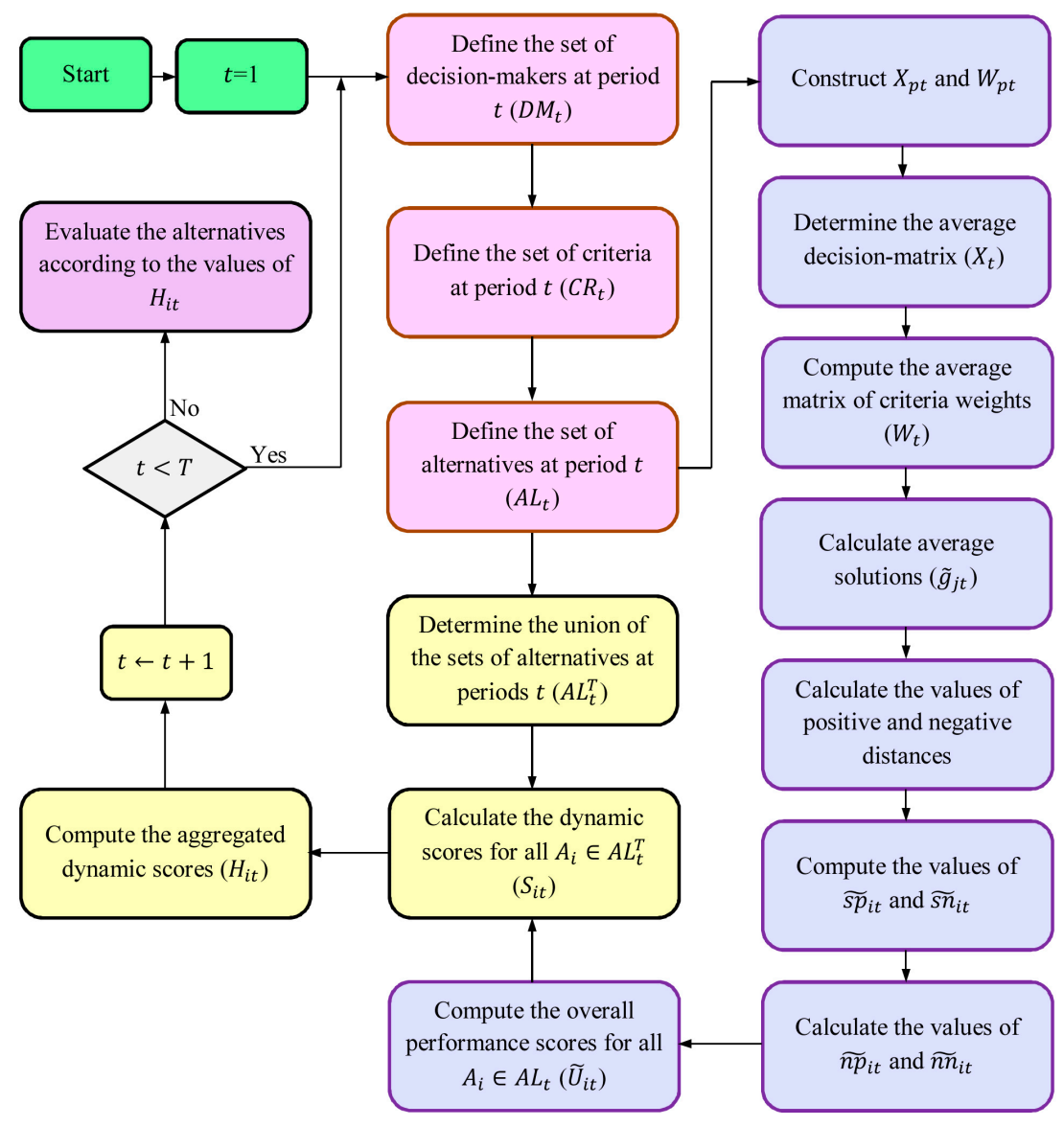

Figure 2. The flowchart of the proposed approach.

\section{Illustrative Example (Subcontractor Evaluation)}

In this section, the proposed approach is applied to a dynamic multi-criteria subcontractor evaluation problem in a construction project. The evaluation process is made by the main contractor of the project in four periods. According to the procedure of the proposed approach, we can define any number of decision-makers, criteria, and alternatives at each period. In this problem, four criteria are defined for evaluation of subcontractors based on the study of Lin, et al. [51]. These criteria are defined as follows: 
- Reliability $\left(C_{1}\right)$ : This criterion is related to evaluation of subcontractors with respect to their records, reputation, and financial condition. It is clear that a subcontractor with good reputation and better financial condition is more favorable.

- Schedule-control ability $\left(C_{2}\right)$ : This criterion is related to the mobilization and efficiency of subcontractors. Activation of the subcontractor's physical and manpower resources for transfer to a construction site until the completion of the contract can be measured by this criterion.

- Management ability $\left(C_{3}\right)$ : The level of safety, quality and environmental management of subcontractors is very important in the overall performance of a subcontractor. This criterion can be used to assess these dimensions of subcontractors.

- Labor quality $\left(C_{4}\right)$ : This criterion can be used for assessment of the level of workers' skill and the coordination of managers and workers. The quality of the outcomes of a construction project is significantly affected by this criterion.

The criteria defined are used in all the periods. In other words, we can define the set of criteria as $C R_{t}=\left\{C_{1}, C_{2}, C_{3}, C_{4}\right\}$ where $t \in\{1,2,3,4\}$. The evaluation process is made based on the assessments of some experts of the main contractor which are considered as decision-makers. In each period, some of the decision-makers may be available and some may be not available for the assessment. In this problem, the sets of decision-makers at each period are as follows:

$D M_{1}=\left\{D_{1}, D_{2}, D_{3}, D_{4}\right\}$,
$D M_{2}=\left\{D_{1}, D_{3}, D_{4}\right\}$,
$D M_{3}=\left\{D_{1}, D_{2}, D_{3}, D_{4}\right\}$,
$D M_{4}=\left\{D_{1}, D_{2}, D_{3}\right\}$.

The number of subcontractors also varies from period to period. Here, we have four sets of alternatives (subcontractors):

$$
\begin{aligned}
& A L_{1}=\left\{A_{1}, A_{2}, A_{3}, A_{4}, A_{5}, A_{6}, A_{7}, A_{8}, A_{9}\right\}, \\
& A L_{2}=\left\{A_{1}, A_{2}, A_{3}, A_{4}, A_{6}, A_{7}, A_{10}, A_{11}, A_{12}, A_{13}\right\}, \\
& A L_{3}=\left\{A_{1}, A_{2}, A_{5}, A_{6}, A_{7}, A_{8}, A_{9}, A_{10}, A_{12}\right\}, \\
& A L_{4}=\left\{A_{2}, A_{3}, A_{6}, A_{7}, A_{8}, A_{10}, A_{13}\right\} .
\end{aligned}
$$

The decision-makers give the importance of criteria and rating of alternatives at each period using linguistic variables. The linguistic variables and their fuzzy equivalents are presented in Table 1 [52]. Because we use a spectrum from "Very poor" to "Very good" for rating of alternatives, all the criteria in the problem should be considered as beneficial criteria. Based on the linguistic variables defined in Table 1, the decision-matrix and the matrix of criteria weights related to each decision-maker can be constructed at each period. The decision-matrices of different periods are presented in Tables 2-6 presents the matrices of criteria weights in different periods.

Based on the steps of the proposed approach and Tables 1-6, we can determine the overall performance scores of alternatives at each period. According to the defuzzified values of overall performance scores, the rank of each alternative at each period can be obtained. The results of each period are shown in Table 7. Also, in this table, we present the ranking results which are obtained by using defuzzified decision-matrices and criteria weights and the TOPSIS method [53]. In addition, to show the validity of the ranking result of each period, the Spearman's rank correlation coefficients $\left(r_{s}\right)$ between the results of the fuzzy EDAS and TOPSIS methods are calculated. As can be seen in Table 7 , all the correlation values are greater than 0.9 , and we can say that there is a strong relationship between the results in all the periods. 
Table 1. The linguistic variables and their fuzzy equivalents.

\begin{tabular}{ccc}
\hline & Linguistic Variables & Triangular Fuzzy Number \\
\hline & Very low (VL) & $(0,0,0.1)$ \\
Low (L) & $(0,0.1,0.3)$ \\
Importance of criteria & Medium low (ML) & $(0.1,0.3,0.5)$ \\
& Medium (M) & $(0.3,0.5,0.7)$ \\
& Medium high (MH) & $(0.5,0.7,0.9)$ \\
& High (H) & $(0.7,0.9,1)$ \\
& Very high (VH) & $(0.9,1,1)$ \\
\hline \multirow{4}{*}{ Rating of alternatives } & Very poor (VP) & $(0,0,1)$ \\
& Poor (P) & $(0,1,3)$ \\
& Medium poor (MP) & $(1,3,5)$ \\
& Fair (F) & $(3,5,7)$ \\
& Medium good (MG) & $(5,7,9)$ \\
& Good (G) & $(7,9,10)$ \\
& Very good (VG) & $(9,10,10)$ \\
\hline
\end{tabular}

Table 2. The decision-matrix of each decision-maker at first period $(t=1)$.

\begin{tabular}{|c|c|c|c|c|c|c|c|c|c|c|c|c|c|c|c|c|}
\hline & \multicolumn{4}{|c|}{$D_{1}$} & \multicolumn{4}{|c|}{$D_{2}$} & \multicolumn{4}{|c|}{$D_{3}$} & \multicolumn{4}{|c|}{$D_{4}$} \\
\hline & $C_{1}$ & $C_{2}$ & $C_{3}$ & $C_{4}$ & $C_{1}$ & $C_{2}$ & $C_{3}$ & $C_{4}$ & $C_{1}$ & $C_{2}$ & $C_{3}$ & $C_{4}$ & $C_{1}$ & $C_{2}$ & $C_{3}$ & $C_{4}$ \\
\hline$A_{1}$ & $\mathrm{P}$ & $\mathrm{F}$ & MP & MP & $\mathrm{P}$ & $\mathrm{P}$ & MP & $\mathrm{P}$ & VP & MP & MP & $\mathrm{P}$ & VP & F & $\mathrm{F}$ & $\mathrm{VP}$ \\
\hline$A_{2}$ & $\mathrm{P}$ & $\mathrm{MP}$ & $\mathrm{P}$ & $\mathrm{P}$ & $\mathrm{MP}$ & F & MP & VP & $\mathrm{MP}$ & MG & $\mathrm{MP}$ & VP & MP & F & $\mathrm{P}$ & $\mathrm{MP}$ \\
\hline$A_{3}$ & $\mathrm{~F}$ & G & MP & G & $\mathrm{F}$ & $\mathrm{F}$ & $\mathrm{F}$ & G & $\mathrm{P}$ & G & MP & G & $\mathrm{P}$ & F & MG & $\mathrm{P}$ \\
\hline$A_{4}$ & VG & G & $\mathrm{G}$ & MG & VG & VG & MG & MG & G & VG & $\mathrm{F}$ & G & G & G & $\mathrm{F}$ & G \\
\hline$A_{5}$ & MG & G & VG & VG & $\mathrm{F}$ & $\mathrm{F}$ & VG & MG & $\mathrm{F}$ & $\mathrm{G}$ & MG & VG & G & $\mathrm{F}$ & MG & G \\
\hline$A_{6}$ & MP & $\mathrm{F}$ & MG & MG & F & F & MG & $\mathrm{F}$ & F & G & MP & $\mathrm{F}$ & MP & G & $\mathrm{F}$ & MP \\
\hline$A_{7}$ & MP & $\mathrm{F}$ & $\mathrm{F}$ & $\mathrm{F}$ & VP & $\mathrm{P}$ & MP & $\mathrm{F}$ & VP & $\mathrm{F}$ & MP & MG & $\mathrm{P}$ & $\mathrm{P}$ & $\mathrm{F}$ & $\mathrm{P}$ \\
\hline$A_{8}$ & $\mathrm{~F}$ & VP & $\mathrm{F}$ & $\mathrm{P}$ & $\mathrm{F}$ & MP & MP & MP & MP & VP & $\mathrm{P}$ & $\mathrm{P}$ & MG & VP & MP & MG \\
\hline$A_{9}$ & F & MG & MG & G & G & MG & VG & $\mathrm{G}$ & G & G & G & F & $\mathrm{G}$ & MG & VG & G \\
\hline
\end{tabular}

Table 3. The decision-matrix of each decision-maker at second period $(t=2)$.

\begin{tabular}{cccccccccccccccccc}
\hline & \multicolumn{1}{c}{$\boldsymbol{D}_{\mathbf{1}}$} & \multicolumn{1}{c}{$\boldsymbol{D}_{\mathbf{2}}$} & \multicolumn{1}{c}{$\boldsymbol{D}_{3}$} & \multicolumn{4}{c}{$D_{4}$} \\
\cline { 2 - 7 } & $C_{\mathbf{1}}$ & $C_{2}$ & $C_{3}$ & $C_{4}$ & $C_{1}$ & $C_{2}$ & $C_{3}$ & $C_{4}$ & $C_{1}$ & $C_{2}$ & $C_{3}$ & $C_{4}$ & $C_{1}$ & $C_{2}$ & $C_{3}$ & $C_{4}$ \\
\hline$A_{1}$ & P & MP & MP & VP & - & - & - & - & P & MP & MG & P & VP & MP & F & MP \\
$A_{2}$ & P & MP & F & VP & - & - & - & - & P & MG & P & VP & VP & MG & MP & P \\
$A_{3}$ & P & F & MP & MG & - & - & - & - & P & MG & MG & G & P & MG & F & F \\
$A_{4}$ & MG & VG & MG & MG & - & - & - & - & MG & G & MG & G & G & G & MG & G \\
$A_{6}$ & P & MG & F & MP & - & - & - & - & P & G & MP & MP & F & G & MG & F \\
$A_{7}$ & P & F & P & MP & - & - & - & - & P & P & MP & F & P & P & F & MG \\
$A_{10}$ & VG & VG & G & MG & - & - & - & - & G & VG & G & G & G & G & G & MG \\
$A_{11}$ & P & MG & G & MG & - & - & - & - & MP & MG & G & MG & F & G & MG & F \\
$A_{12}$ & P & VP & P & MP & - & - & - & - & VP & VP & MP & P & VP & VP & P & MP \\
$A_{13}$ & MG & P & VP & MP & - & - & - & - & MP & P & P & P & F & MP & P & MP \\
\hline
\end{tabular}

Table 4. The decision-matrix of each decision-maker at third period $(t=3)$.

\begin{tabular}{|c|c|c|c|c|c|c|c|c|c|c|c|c|c|c|c|c|}
\hline & \multicolumn{4}{|c|}{$D_{1}$} & \multicolumn{4}{|c|}{$D_{2}$} & \multicolumn{4}{|c|}{$D_{3}$} & \multicolumn{4}{|c|}{$D_{4}$} \\
\hline & $C_{1}$ & $C_{2}$ & $C_{3}$ & $C_{4}$ & $C_{1}$ & $C_{2}$ & $C_{3}$ & $C_{4}$ & $C_{1}$ & $C_{2}$ & $C_{3}$ & $C_{4}$ & $C_{1}$ & $C_{2}$ & $C_{3}$ & $C_{4}$ \\
\hline$A_{1}$ & $\mathrm{P}$ & $\mathrm{P}$ & MP & $\mathrm{P}$ & VP & $\mathrm{F}$ & MP & MP & $\mathrm{P}$ & MP & $\mathrm{F}$ & MP & VP & $\mathrm{F}$ & F & MP \\
\hline$A_{2}$ & MP & F & $\mathrm{P}$ & VP & VP & MP & $\mathrm{P}$ & $\mathrm{P}$ & $\mathrm{P}$ & MG & F & MP & MP & MP & F & $\mathrm{MP}$ \\
\hline$A_{5}$ & MG & G & MG & VG & $\mathrm{F}$ & $G$ & MG & MG & MG & G & VG & $G$ & $G$ & $\mathrm{~F}$ & G & MG \\
\hline$A_{6}$ & $\mathrm{P}$ & G & MG & MP & MP & MG & $\mathrm{F}$ & $\mathrm{F}$ & MP & $\mathrm{F}$ & $\mathrm{F}$ & MP & $\mathrm{P}$ & $\mathrm{F}$ & MG & $\mathrm{F}$ \\
\hline$A_{7}$ & VP & $\mathrm{P}$ & $\mathrm{MP}$ & MG & $\mathrm{MP}$ & $\mathrm{MP}$ & $\mathrm{MP}$ & F & VP & $\mathrm{F}$ & $\mathrm{P}$ & F & VP & $\mathrm{MP}$ & $\mathrm{P}$ & $\mathrm{MP}$ \\
\hline$A_{8}$ & F & $\mathrm{MP}$ & $\mathrm{F}$ & $\mathrm{P}$ & MG & MP & $\mathrm{P}$ & MP & MG & $\mathrm{P}$ & F & MP & MG & $\mathrm{P}$ & $\mathrm{F}$ & $\mathrm{F}$ \\
\hline$A_{9}$ & MG & $\mathrm{G}$ & VG & F & MG & $\mathrm{G}$ & VG & $\mathrm{F}$ & G & VG & G & $\mathrm{F}$ & MG & VG & VG & G \\
\hline$A_{10}$ & $\mathrm{G}$ & G & $\mathrm{G}$ & G & MG & G & VG & MG & G & G & G & $\mathrm{F}$ & MG & VG & VG & G \\
\hline$A_{12}$ & VP & $\mathrm{P}$ & $\mathrm{P}$ & $\mathrm{P}$ & $\mathrm{P}$ & $\mathrm{P}$ & $\mathrm{P}$ & $\mathrm{F}$ & MP & VP & MP & $\mathrm{F}$ & $\mathrm{P}$ & $\mathrm{P}$ & $\mathrm{P}$ & $\mathrm{F}$ \\
\hline
\end{tabular}


Table 5. The decision-matrix of each decision-maker at fourth period $(t=4)$.

\begin{tabular}{|c|c|c|c|c|c|c|c|c|c|c|c|c|c|c|c|c|}
\hline & \multicolumn{4}{|c|}{$D_{1}$} & \multicolumn{4}{|c|}{$D_{2}$} & \multicolumn{4}{|c|}{$D_{3}$} & \multicolumn{4}{|c|}{$D_{4}$} \\
\hline & $C_{1}$ & $C_{2}$ & $C_{3}$ & $C_{4}$ & $C_{1}$ & $C_{2}$ & $C_{3}$ & $C_{4}$ & $C_{1}$ & $C_{2}$ & $C_{3}$ & $C_{4}$ & $C_{1}$ & $C_{2}$ & $C_{3}$ & $C_{4}$ \\
\hline$A_{2}$ & MP & MG & $\mathrm{F}$ & $\mathrm{P}$ & MP & MP & $\mathrm{F}$ & MP & MP & MG & MP & VP & - & - & - & - \\
\hline$A_{3}$ & $\mathrm{~F}$ & MG & MP & $\mathrm{F}$ & $\mathrm{F}$ & G & MG & MG & $\mathrm{MP}$ & $\mathrm{F}$ & $\mathrm{MP}$ & $\mathrm{F}$ & - & - & - & - \\
\hline$A_{6}$ & $\mathrm{MP}$ & $\mathrm{F}$ & $\mathrm{F}$ & $\mathrm{MP}$ & $\mathrm{MP}$ & MG & MP & MG & $\mathrm{P}$ & $\mathrm{F}$ & $\mathrm{F}$ & $\mathrm{MP}$ & - & - & - & - \\
\hline$A_{7}$ & VP & $\mathrm{P}$ & $\mathrm{P}$ & $\mathrm{MP}$ & $\mathrm{P}$ & $\mathrm{F}$ & MP & $\mathrm{F}$ & $\mathrm{MP}$ & MP & $\mathrm{P}$ & MP & - & - & - & - \\
\hline$A_{8}$ & MP & $\mathrm{P}$ & $\mathrm{P}$ & $\mathrm{MP}$ & $\mathrm{MP}$ & VP & MP & $\mathrm{MP}$ & $\mathrm{MP}$ & VP & $\mathrm{MP}$ & $\mathrm{F}$ & - & - & - & - \\
\hline$A_{10}$ & MG & G & VG & G & VG & VG & $\mathrm{G}$ & MG & VG & G & $\mathrm{G}$ & G & - & - & - & - \\
\hline$A_{13}$ & MP & VP & VP & $\mathrm{P}$ & $\mathrm{F}$ & VP & VP & MP & MG & MP & $\mathrm{P}$ & VP & - & - & - & - \\
\hline
\end{tabular}

Table 6. The matrices of criteria weights in different periods.

\begin{tabular}{|c|c|c|c|c|c|}
\hline & & $D_{1}$ & $D_{2}$ & $D_{3}$ & $D_{4}$ \\
\hline \multirow{4}{*}{$t=1$} & $C_{1}$ & ML & $\mathrm{L}$ & $\mathrm{M}$ & $\mathrm{M}$ \\
\hline & $C_{2}$ & $\mathrm{M}$ & ML & $\mathrm{M}$ & $\mathrm{M}$ \\
\hline & $C_{3}$ & $\mathrm{MH}$ & $\mathrm{VH}$ & $\mathrm{MH}$ & $\mathrm{H}$ \\
\hline & $C_{4}$ & $\mathrm{H}$ & $\mathrm{MH}$ & $\mathrm{M}$ & $\mathrm{MH}$ \\
\hline \multirow{4}{*}{$t=2$} & $C_{1}$ & $\mathrm{~L}$ & - & ML & $\mathrm{L}$ \\
\hline & $C_{2}$ & ML & - & $\mathrm{M}$ & $\mathrm{M}$ \\
\hline & $C_{3}$ & $\mathrm{VH}$ & - & $\mathrm{VH}$ & $\mathrm{MH}$ \\
\hline & $C_{4}$ & $\mathrm{H}$ & - & MH & $\mathrm{M}$ \\
\hline \multirow{4}{*}{$t=3$} & $C_{1}$ & $\mathrm{~L}$ & $\mathrm{~L}$ & $\mathrm{M}$ & $\mathrm{L}$ \\
\hline & $C_{2}$ & ML & ML & MH & ML \\
\hline & $C_{3}$ & $\mathrm{MH}$ & $\mathrm{MH}$ & $\mathrm{H}$ & $\mathrm{VH}$ \\
\hline & $C_{4}$ & $\mathrm{M}$ & $\mathrm{M}$ & M & $\mathrm{H}$ \\
\hline \multirow{4}{*}{$t=4$} & $C_{1}$ & ML & $\mathrm{M}$ & $\mathrm{L}$ & - \\
\hline & $C_{2}$ & ML & ML & $\mathrm{MH}$ & - \\
\hline & $C_{3}$ & $\mathrm{MH}$ & $\mathrm{MH}$ & $\mathrm{H}$ & - \\
\hline & $C_{4}$ & $\mathrm{MH}$ & $\mathrm{MH}$ & $\mathrm{H}$ & - \\
\hline
\end{tabular}

According to the results presented in Table 7 and Steps 12 and 13 of the proposed approach, the dynamic and aggregated dynamic scores of alternatives can be calculated.

It should be noted that we use Equation (29) to set the weights for aggregating the dynamic scores. However, this function can be replaced with any custom function which can consider the importance of newer decision information. Also, the user of the proposed approach can set the weights manually without defining a function.

The values of $S_{i t}, H_{i t}$ and the rank of each alternative related to each period are represented in Table 8. We also show the changes in the members of $A L_{t}$ and $A L_{t}^{T}$ in this table. The members of these sets should be known for the calculations of Steps 12 and 13."

As it can be seen in Table $8, A_{9}$ is the best alternative (subcontractor) in the first period $(t=1)$, but this alternative is not available in the second period. The unavailability of $A_{9}$, and availability of some better alternatives in the second period lead to a decrease in the value of the aggregated dynamic score for this alternative. Therefore, the rank of $A_{9}$ is changed from 1 to 6 at $t=2$. On the other hand, the rank of $A_{4}$, which has the second rank at $t=1$, is changed to 1 in the second period, and $A_{10}$, which is a new available subcontractor, has the second rank in the second period. We can say that the rank of alternatives is dynamic and changes in different periods according to the new information of decision-making process.

In this example, the changes in the rank of subcontractors at different time periods are depicted in Figure 3. 
Table 7. The overall performance scores and ranking results at each period.

\begin{tabular}{|c|c|c|c|c|c|}
\hline & & \multirow{2}{*}{$\widetilde{U}_{i t}$} & \multirow{2}{*}{$\mathfrak{D}\left(\widetilde{U}_{i t}\right)$} & \multicolumn{2}{|c|}{ Rank } \\
\hline & & & & Fuzzy EDAS & TOPSIS \\
\hline \multirow{10}{*}{$t=1$} & $A_{1}$ & $(-0.716,0.05,0.67)$ & 0.0013 & 8 & 9 \\
\hline & $A_{2}$ & $(-0.712,0.0290,0.683)$ & 0 & 9 & 8 \\
\hline & $A_{3}$ & $(-0.0580,0.617,1.305)$ & 0.6216 & 4 & 4 \\
\hline & $A_{4}$ & $(0.349,0.914,1.614)$ & 0.9591 & 2 & 3 \\
\hline & $A_{5}$ & $(0.366,0.898,1.562)$ & 0.9421 & 3 & 2 \\
\hline & $A_{6}$ & $(-0.137,0.550,1.258)$ & 0.5572 & 5 & 5 \\
\hline & $A_{7}$ & $(-0.524,0.252,0.903)$ & 0.2105 & 6 & 6 \\
\hline & $A_{8}$ & $(-0.639,0.101,0.757)$ & 0.0730 & 7 & 7 \\
\hline & $A_{9}$ & $(0.415,0.953,1.632)$ & 1 & 1 & 1 \\
\hline & & & & \multicolumn{2}{|c|}{$r_{s}=0.97$} \\
\hline \multirow{11}{*}{$t=2$} & $A_{1}$ & $(-0.402,0.263,0.762)$ & 0.2075 & 7 & 7 \\
\hline & $A_{2}$ & $(-0.453,0.166,0.707)$ & 0.1402 & 8 & 8 \\
\hline & $A_{3}$ & $(0.037,0.59,1.125)$ & 0.5838 & 4 & 4 \\
\hline & $A_{4}$ & $(0.439,0.874,1.472)$ & 0.9281 & 2 & 2 \\
\hline & $A_{6}$ & $(-0.089,0.517,1.111)$ & 0.5130 & 5 & 5 \\
\hline & $A_{7}$ & $(-0.353,0.309,0.874)$ & 0.2767 & 6 & 6 \\
\hline & $A_{10}$ & $(0.514,0.965,1.522)$ & 1 & 1 & 1 \\
\hline & $A_{11}$ & $(0.249,0.77,1.334)$ & 0.7843 & 3 & 3 \\
\hline & $A_{12}$ & $(-0.636,0.041,0.595)$ & 0 & 10 & 10 \\
\hline & $A_{13}$ & $(-0.526,0.091,0.694)$ & 0.0864 & 9 & 9 \\
\hline & & & & \multicolumn{2}{|c|}{$r_{s}=1$} \\
\hline \multirow{10}{*}{$t=3$} & $A_{1}$ & $(-0.652,0.194,0.848)$ & 0.1298 & 7 & 7 \\
\hline & $A_{2}$ & $(-0.65,0.15,0.801)$ & 0.1005 & 8 & 8 \\
\hline & $A_{5}$ & $(0.436,0.875,1.501)$ & 0.9376 & 3 & 2 \\
\hline & $A_{6}$ & $(-0.215,0.489,1.144)$ & 0.4725 & 4 & 4 \\
\hline & $A_{7}$ & $(-0.569,0.184,0.782)$ & 0.1324 & 6 & 6 \\
\hline & $A_{8}$ & $(-0.473,0.278,0.991)$ & 0.2652 & 5 & 5 \\
\hline & $A_{9}$ & $(0.448,0.9,1.482)$ & 0.9434 & 2 & 3 \\
\hline & $A_{10}$ & $(0.503,0.947,1.55)$ & 1 & 1 & 1 \\
\hline & $A_{12}$ & $(-0.745,0.05,0.695)$ & 0 & 9 & 9 \\
\hline & & & & \multicolumn{2}{|c|}{$r_{S}=0.98$} \\
\hline \multirow{8}{*}{$t=4$} & $A_{2}$ & $(-0.26,0.357,0.93)$ & 0.3424 & 4 & 4 \\
\hline & $A_{3}$ & $(0.179,0.614,1.102)$ & 0.6318 & 2 & 2 \\
\hline & $A_{6}$ & $(-0.026,0.507,1.016)$ & 0.4992 & 3 & 3 \\
\hline & $A_{7}$ & $(-0.586,0.242,0.946)$ & 0.2007 & 6 & 6 \\
\hline & $A_{8}$ & $(-0.592,0.244,0.969)$ & 0.2070 & 5 & 5 \\
\hline & $A_{10}$ & $(0.59,0.971,1.438)$ & 1 & 1 & 1 \\
\hline & $A_{13}$ & $(-0.599,0.043,0.611)$ & 0.0183 & 7 & 7 \\
\hline & & & & \multicolumn{2}{|c|}{$r_{S}=1$} \\
\hline
\end{tabular}

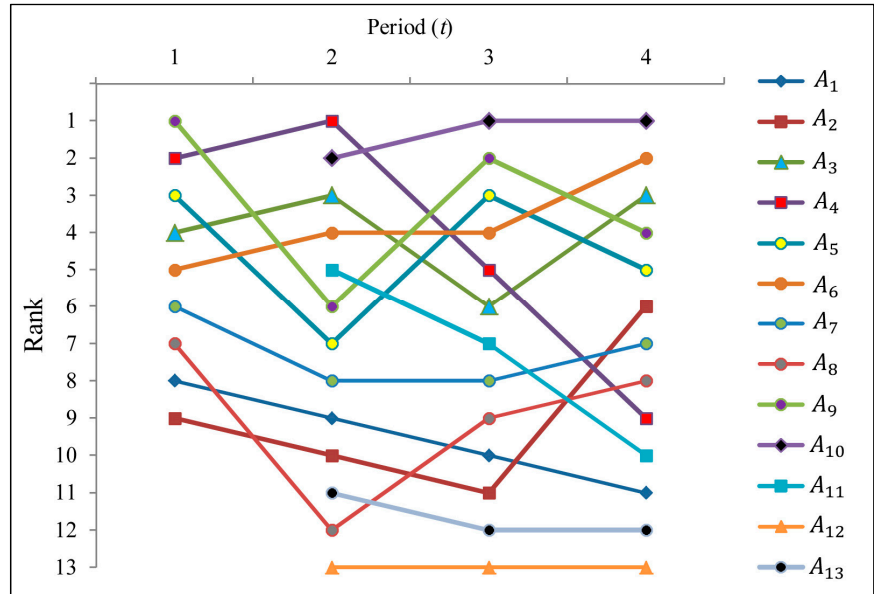

Figure 3. The changes in the rank of alternatives at different time periods. 
Table 8. The final scores and ranks of alternatives at each period.

\begin{tabular}{|c|c|c|c|c|c|c|c|c|c|c|c|c|c|c|}
\hline & & $A_{1}$ & $A_{2}$ & $A_{3}$ & $A_{4}$ & $A_{5}$ & $A_{6}$ & $A_{7}$ & $A_{8}$ & $A_{9}$ & $A_{10}$ & $A_{11}$ & $A_{12}$ & $A_{13}$ \\
\hline \multirow{5}{*}{$t=1$} & $A L_{t}$ & $\sqrt{ }$ & $\sqrt{ }$ & $\sqrt{ }$ & $\sqrt{ }$ & $\sqrt{ }$ & $\sqrt{ }$ & $\sqrt{ }$ & $\sqrt{ }$ & $\sqrt{ }$ & $x$ & $x$ & $x$ & $x$ \\
\hline & $A L_{t}^{T}$ & $\sqrt{ }$ & $\sqrt{ }$ & $\sqrt{ }$ & $\sqrt{ }$ & $\sqrt{ }$ & $\sqrt{ }$ & $\sqrt{ }$ & $\sqrt{ }$ & $\sqrt{ }$ & $x$ & $x$ & $x$ & $x$ \\
\hline & $S_{i t}^{t}$ & 0.0013 & 0 & 0.6216 & 0.9591 & 0.9421 & 0.5572 & 0.2105 & 0.0730 & 1 & - & - & - & - \\
\hline & $H_{i t}$ & 0.0013 & 0 & 0.6216 & 0.9591 & 0.9421 & 0.5572 & 0.2105 & 0.0730 & 1 & - & - & - & - \\
\hline & Rank & 8 & 9 & 4 & 2 & 3 & 5 & 6 & 7 & 1 & - & - & - & - \\
\hline \multirow{5}{*}{$t=2$} & $A L_{t}$ & $\sqrt{ }$ & $\sqrt{ }$ & $\sqrt{ }$ & $\sqrt{ }$ & $\times$ & $\sqrt{ }$ & $\sqrt{ }$ & $\times$ & $\times$ & $\sqrt{ }$ & $\sqrt{ }$ & $\sqrt{ }$ & $\sqrt{ }$ \\
\hline & $A L_{t}^{T}$ & $\sqrt{ }$ & $\sqrt{ }$ & $\sqrt{ }$ & $\sqrt{ }$ & $\sqrt{ }$ & $\sqrt{ }$ & $\sqrt{ }$ & $\sqrt{ }$ & $\sqrt{ }$ & $\sqrt{ }$ & $\sqrt{ }$ & $\sqrt{ }$ & $\sqrt{ }$ \\
\hline & $S_{i t}$ & 0.2075 & 0.1402 & 0.5838 & 0.9281 & 0 & 0.5130 & 0.2767 & 0 & 0 & 1 & 0.7843 & 0 & 0.0864 \\
\hline & $H_{i t}$ & 0.1388 & 0.0935 & 0.5964 & 0.9384 & 0.314 & 0.5277 & 0.2546 & 0.0243 & 0.3333 & 0.6667 & 0.5229 & 0 & 0.0576 \\
\hline & Rank & 9 & 10 & 3 & 1 & 7 & 4 & 8 & 12 & 6 & 2 & 5 & 13 & 11 \\
\hline \multirow{5}{*}{$t=3$} & $A L_{t}$ & $\sqrt{ }$ & $\sqrt{ }$ & $\times$ & $\times$ & $\sqrt{ }$ & $\sqrt{ }$ & $\sqrt{ }$ & $\sqrt{ }$ & $\sqrt{ }$ & $\sqrt{ }$ & $\times$ & $\sqrt{ }$ & $\times$ \\
\hline & $A L_{t}^{T}$ & $\sqrt{ }$ & $\sqrt{ }$ & $\sqrt{ }$ & $\sqrt{ }$ & $\sqrt{ }$ & $\sqrt{ }$ & $\sqrt{ }$ & $\sqrt{ }$ & $\sqrt{ }$ & $\sqrt{ }$ & $\sqrt{ }$ & $\sqrt{ }$ & $\sqrt{ }$ \\
\hline & $S_{i t}^{t}$ & 0.1298 & 0.1005 & 0 & 0 & 0.9376 & 0.4725 & 0.1324 & 0.2652 & 0.9434 & 1 & 0 & 0 & 0 \\
\hline & $H_{i t}$ & 0.1334 & 0.0977 & 0.2386 & 0.3754 & 0.6882 & 0.4946 & 0.1813 & 0.1689 & 0.6994 & 0.8667 & 0.2091 & 0 & 0.023 \\
\hline & Rank & 10 & 11 & 6 & 5 & 3 & 4 & 8 & 9 & 2 & 1 & 7 & 13 & 12 \\
\hline \multirow{5}{*}{$t=4$} & $A L_{t}$ & $\times$ & $\sqrt{ }$ & $\sqrt{ }$ & $\times$ & $x$ & $\sqrt{ }$ & $\sqrt{ }$ & $\sqrt{ }$ & $\times$ & $\sqrt{ }$ & $\times$ & $\times$ & $\sqrt{ }$ \\
\hline & $A L_{t}^{T}$ & $\sqrt{ }$ & $\sqrt{ }$ & $\sqrt{ }$ & $\sqrt{ }$ & $\sqrt{ }$ & $\sqrt{ }$ & $\sqrt{ }$ & $\sqrt{ }$ & $\sqrt{ }$ & $\sqrt{ }$ & $\sqrt{ }$ & $\sqrt{ }$ & $\sqrt{ }$ \\
\hline & $S_{i t}$ & 0 & 0.3424 & 0.6318 & 0 & 0 & 0.4992 & 0.2007 & 0.2070 & 0 & 1 & 0 & 0 & 0.0183 \\
\hline & $H_{i t}$ & 0.0572 & 0.2375 & 0.4633 & 0.1609 & 0.2949 & 0.4972 & 0.1924 & 0.1907 & 0.2997 & 0.9429 & 0.0896 & 0 & 0.0203 \\
\hline & Rank & 11 & 6 & 3 & 9 & 5 & 2 & 7 & 8 & 4 & 1 & 10 & 13 & 12 \\
\hline
\end{tabular}

According to the evaluation of the last period $(t=4), A_{10}$ is the best alternative, and the final ranking is as follows:

$$
A_{10} \succ A_{6} \succ A_{3} \succ A_{9} \succ A_{5} \succ A_{2} \succ A_{7} \succ A_{8} \succ A_{4} \succ A_{11} \succ A_{13} \succ A_{12}
$$

Although the final evaluation can be made based on the above-mentioned ranking, the main contractor should be cautious about the subcontractors which have higher degree of fluctuation in their ranks at different periods. The fluctuation in the rank of subcontractors could be occurred due to the unavailability of them or their low performance in some periods. Both reasons lead to unreliability of a subcontractor. As we can see in Figure 3, the ranks of $A_{10}, A_{6}, A_{7}, A_{12}$ and $A_{13}$ have lower fluctuation than the other alternatives. Therefore, the main contractor can select $A_{10}$ as a reliable subcontractor and consider $A_{6}$ as a backup alternative.

\section{Conclusions}

In the management of a contract, it has become usual to outsource specialized tasks by the main contractor. This can be done to ensure the quality of construction projects. Although outsourcing most tasks to a subcontractor is convenient and safe for the main contractor, the failure of the selected subcontractor can lead to the failure of the entire project. Hence the process of evaluation and selection of subcontractors can be considered as one of the important actions that should be carried out by the main contractor.

In this study, we have defined the subcontractor evaluation process as a dynamic multi-criteria group decision-making problem. Due to the uncertainty of information in the process of evaluation, a fuzzy dynamic MCGDM approach has been proposed to deal with SEP. The proposed approach has been designed based on the EDAS method which is a new and efficient MCDM approach. In the procedure of the proposed approach, we can define different sets of alternatives, criteria, and decision-makers in different time periods. The performance of each alternative is updated in each period by an aggregation function which gives greater weights to newer information. Thus, we can ensure that the final evaluation involves the importance of up-to-date decision information.

We have used an example of subcontractor evaluation problem to illustrate the process of the proposed approach and show the utility of it in real-world decision-making problems. Because the weights of criteria as well as the set of criteria can be changed at each period in the process of using the proposed dynamic approach, the sensitivity analysis on the weights of criteria has not been made in 
this study. Lack of this analysis can be considered as a limitation of this study. To make the sensitivity analysis in the proposed approach, we need to devise a new research methodology, and this can be addressed in future research. Also, future research can examine the effect of different weight functions for aggregation of the dynamic scores of alternatives and apply the proposed approach to the other MCDM problems such as supplier evaluation, service quality assessment and risk evaluation. Moreover, other types of fuzzy sets such as interval type-2 fuzzy sets, intuitionistic fuzzy sets and hesitant fuzzy sets can be used to extend the propose approach.

Author Contributions: Mehdi Keshavarz-Ghorabaee, Maghsoud Amiri and Edmundas Kazimieras Zavadskas designed the research, analyzed the data and the obtained results, and performed the development of the paper. Zenonas Turskis and Jurgita Antucheviciene provided extensive advice throughout the study, regarding the research design, methodology, findings and revised the manuscript. All the authors have read and approved the final manuscript.

Conflicts of Interest: The authors declare no conflict of interest.

\section{References}

1. Hinze, J.; Tracey, A. The contractor-subcontractor relationship: The subcontractor's view. J. Constr. Eng. Manag. 1994, 120, 274-287. [CrossRef]

2. Polat, G. Subcontractor selection using the integration of the ahp and promethee methods. J. Civ. Eng. Manag. 2016, 22, 1042-1054. [CrossRef]

3. Hartmann, A.; Ling, F.Y.Y.; Tan, J.S. Relative importance of subcontractor selection criteria: Evidence from singapore. J. Constr. Eng. Manag. 2009, 135, 826-832. [CrossRef]

4. Arslan, G.; Kivrak, S.; Birgonul, M.T.; Dikmen, I. Improving sub-contractor selection process in construction projects: Web-based sub-contractor evaluation system (WEBSES). Autom. Constr. 2008, 17, 480-488. [CrossRef]

5. Zhao, J.; Yu, L.; Li, L. Application of GRA method, dynamic analysis and fuzzy set theory in evaluation and selection of emergency treatment technology for large scale phenol spill incidents. AIP Conf. Proc. 2017, 1839, $1-6$.

6. Keshavarz Ghorabaee, M.; Amiri, M.; Zavadskas, E.K.; Antucheviciene, J. Supplier evaluation and selection in fuzzy environments: A review of madm approaches. Econ. Res. Ekon. Istraž. 2017, 30, 1073-1118. [CrossRef]

7. Sun, Y.; Zhang, G.; Hong, Z.; Dong, K. How uncertain information on service capacity influences the intermodal routing decision: A fuzzy programming perspective. Information 2018, 9, 24. [CrossRef]

8. Wu, Y.; Liu, L.; Gao, J.; Chu, H.; Xu, C. An extended vikor-based approach for pumped hydro energy storage plant site selection with heterogeneous information. Information 2017, 8, 106. [CrossRef]

9. Wang, R.; Li, Y. Generalized single-valued neutrosophic hesitant fuzzy prioritized aggregation operators and their applications to multiple criteria decision-making. Information 2018, 9, 10. [CrossRef]

10. Lu, Z.; Ye, J. Exponential operations and an aggregation method for single-valued neutrosophic numbers in decision making. Information 2017, 8, 62. [CrossRef]

11. Gao, J.; Liu, H. A new prospect projection multi-criteria decision-making method for interval-valued intuitionistic fuzzy numbers. Information 2016, 7, 64. [CrossRef]

12. Cheng, M.; Ma, G.X.; Sun, J.K. AHP-based research on the selection of construction project subcontractor. Adv. Mater. Res. 2012, 594-597, 3035-3039. [CrossRef]

13. Kargi, V.S.A.; Öztürk, A. Subcontractor selection using analytic hierarchy process. Bus. Econ. Res. J. 2012, 3, $121-143$.

14. Yayla, A.Y.; Yildiz, A.; Yildiz, K. Generalised Choquet integral algorithm for subcontractor selection in the textile industry-A case study for turkey. Fibres Text. East. Eur. 2013, 21, 16-21.

15. Ng, S.T.; Skitmore, M. Developing a framework for subcontractor appraisal using a balanced scorecard. J. Civ. Eng. Manag. 2014, 20, 149-158. [CrossRef]

16. Abbasianjahromi, H.; Rajaie, H.; Shakeri, E. A framework for subcontractor selection in the construction industry. J. Civ. Eng. Manag. 2013, 19, 158-168. [CrossRef]

17. Shahvand, E.; Sebt, M.; Banki, M. Developing fuzzy expert system for supplier and subcontractor evaluation in construction industry. Sci. Iran. Trans. A Civ. Eng. 2016, 23, 842-855. [CrossRef]

18. Ulubeyli, S.; Kazaz, A. Fuzzy multi-criteria decision making model for subcontractor selection in international construction projects. Technol. Econ. Dev. Econ. 2016, 22, 210-234. [CrossRef] 
19. Abbasianjahromi, H.; Rajaie, H.; Shakeri, E.; Kazemi, O. A new approach for subcontractor selection in the construction industry based on portfolio theory. J. Civ. Eng. Manag. 2016, 22, 346-356. [CrossRef]

20. Polat, G.; Cetindere, F.; Damci, A.; Bingol, B.N. Smart home subcontractor selection using the integration of ahp and evidential reasoning approaches. Procedia Eng. 2016, 164, 347-353. [CrossRef]

21. Campanella, G.; Ribeiro, R.A. A framework for dynamic multiple-criteria decision making. Decis. Support Syst. 2011, 52, 52-60. [CrossRef]

22. Wei, G. Grey relational analysis model for dynamic hybrid multiple attribute decision making. Knowl. Based Syst. 2011, 24, 672-679. [CrossRef]

23. Chen, Y.; Li, B. Dynamic multi-attribute decision making model based on triangular intuitionistic fuzzy numbers. Sci. Iran. 2011, 18, 268-274. [CrossRef]

24. Wang, Y.; Shi, X.; Sun, J.; Qian, W. A grey interval relational degree-based dynamic multiattribute decision making method and its application in investment decision making. Math. Probl. Eng. 2014, 2014, 6. [CrossRef]

25. Junhua, H.; Peng, C.; Liu, Y. Dynamic stochastic multi-criteria decision making method based on prospect theory and conjoint analysis. Manag. Sci. Eng. 2014, 8, 65-71.

26. Li, G.; Kou, G.; Peng, Y. Dynamic fuzzy multiple criteria decision making for performance evaluation. Technol. Econ. Dev. Econ. 2015, 21, 705-719. [CrossRef]

27. Yan, S.; Liu, S.; Liu, J.; Wu, L. Dynamic grey target decision making method with grey numbers based on existing state and future development trend of alternatives. J. Intell. Fuzzy Syst. 2015, 28, 2159-2168. [CrossRef]

28. Liu, J.; Guo, L.; Jiang, J.; Hao, L.; Liu, R.; Wang, P. Evaluation and selection of emergency treatment technology based on dynamic fuzzy GRA method for chemical contingency spills. J. Hazard. Mater. 2015, 299, 306-315. [CrossRef] [PubMed]

29. Yan, S.; Liu, S.; Liu, X. Dynamic grey target decision making method with three-parameter grey numbers. Grey Syst. Theory Appl. 2016, 6, 169-179. [CrossRef]

30. Keshavarz Ghorabaee, M.; Zavadskas, E.K.; Olfat, L.; Turskis, Z. Multi-criteria inventory classification using a new method of evaluation based on distance from average solution (EDAS). Informatica 2015, 26, 435-451. [CrossRef]

31. Keshavarz Ghorabaee, M.; Zavadskas, E.K.; Amiri, M.; Turskis, Z. Extended EDAS method for fuzzy multi-criteria decision-making: An application to supplier selection. Int. J. Comput. Commun. Control 2016, 11, 358-371. [CrossRef]

32. Kahraman, C.; Keshavarz Ghorabaee, M.; Zavadskas, E.K.; Cevik Onar, S.; Yazdani, M.; Oztaysi, B. Intuitionistic fuzzy EDAS method: An application to solid waste disposal site selection. J. Environ. Eng. Landsc. Manag. 2017, 25, 1-12. [CrossRef]

33. Karaşan, A.; Kahraman, C. Interval-valued neutrosophic extension of EDAS method. In Advances in Fuzzy Logic and Technology 2017, Proceedings of the 10th Conference of the European Society for Fuzzy Logic and Technology (EUSFLAT 2017), Warsaw, Poland, 11-15 September 2017; Kacprzyk, J., Szmidt, E., Zadrożny, S., Atanassov, K.T., Krawczak, M., Eds.; Springer: Cham, Switzerland, 2018; Volume 2, pp. 343-357.

34. Peng, X.; Dai, J.; Yuan, H. Interval-valued fuzzy soft decision making methods based on MABAC, similarity measure and EDAS. Fundam. Inform. 2017, 152, 373-396. [CrossRef]

35. Peng, X.; Liu, C. Algorithms for neutrosophic soft decision making based on EDAS, new similarity measure and level soft set. J. Intell. Fuzzy Syst. 2017, 32, 955-968. [CrossRef]

36. Stanujkic, D.; Zavadskas, E.K.; Keshavarz Ghorabaee, M.; Turskis, Z. An extension of the EDAS method based on the use of interval grey numbers. Stud. Inform. Control 2017, 26, 5-12. [CrossRef]

37. Keshavarz Ghorabaee, M.; Amiri, M.; Zavadskas, E.K.; Turskis, Z. Multi-criteria group decision-making using an extended EDAS method with interval type-2 fuzzy sets. E M Ekon. Manag. 2017, 20, 48-68.

38. Ren, J.; Toniolo, S. Life cycle sustainability decision-support framework for ranking of hydrogen production pathways under uncertainties: An interval multi-criteria decision making approach. J. Clean. Prod. 2018, 175, 222-236. [CrossRef]

39. Stević, Ž.; Pamučar, D.; Vasiljević, M.; Stojić, G.; Korica, S. Novel integrated multi-criteria model for supplier selection: Case study construction company. Symmetry 2017, 9, 279. [CrossRef]

40. Juodagalvienè, B.; Turskis, Z.; Šaparauskas, J.; Endriukaitytė, A. Integrated multi-criteria evaluation of house's plan shape based on the EDAS and SWARA methods. Eng. Struct. Technol. 2017, 9, 117-125. [CrossRef] 
41. Turskis, Z.; Morkunaite, Z.; Kutut, V. A hybrid multiple criteria evaluation method of ranking of cultural heritage structures for renovation projects. Int. J. Strateg. Prop. Manag. 2017, 21, 318-329. [CrossRef]

42. Trinkūnienè, E.; Podvezko, V.; Zavadskas, E.K.; Jokšienè, I.; Vinogradova, I.; Trinkūnas, V. Evaluation of quality assurance in contractor contracts by multi-attribute decision-making methods. Econ. Res. Ekon. Istraž. 2017, 30, 1152-1180. [CrossRef]

43. Ecer, F. Third-party logistics (3pls) provider selection via fuzzy AHP and EDAS integrated model. Technol. Econ. Dev. Econ. 2018, 24, 615-634. [CrossRef]

44. Stević, Ž.; Vasiljević, M.; Vesković, S. Evaluation in logistics using combined AHP and EDAS method. In Proceedings of the XLIII International Symposium on Operational Research, Belgrade, Serbia, 20-23 September 2016; pp. 309-313.

45. Turskis, Z.; Juodagalvienè, B. A novel hybrid multi-criteria decision-making model to assess a stairs shape for dwelling houses. J. Civ. Eng. Manag. 2016, 22, 1078-1087. [CrossRef]

46. Zadeh, L.A. Fuzzy sets. Inf. Control 1965, 8, 338-353. [CrossRef]

47. Zimmermann, H.J. Fuzzy set theory. Wiley Interdiscip. Rev. Comput. Stat. 2010, 2, 317-332. [CrossRef]

48. Wang, Y.-J.; Lee, H.-S. Generalizing topsis for fuzzy multiple-criteria group decision-making. Comput. Math. Appl. 2007, 53, 1762-1772. [CrossRef]

49. Chen, S.-J.; Hwang, C.-L. Fuzzy Multiple Attribute Decision Making: Methods and Applications; Springer: Berlin/Heidelberg, Germany, 1992.

50. Wang, Y.-M.; Yang, J.-B.; Xu, D.-L.; Chin, K.-S. On the centroids of fuzzy numbers. Fuzzy Sets Syst. 2006, 157, 919-926. [CrossRef]

51. Lin, Y.-H.; Lee, P.-C.; Ting, H.-I. Dynamic multi-attribute decision making model with grey number evaluations. Expert Syst. Appl. 2008, 35, 1638-1644. [CrossRef]

52. Chen, C.-T. Extensions of the TOPSIS for group decision-making under fuzzy environment. Fuzzy Sets Syst. 2000, 114, 1-9. [CrossRef]

53. Opricovic, S.; Tzeng, G.-H. Compromise solution by mcdm methods: A comparative analysis of VIKOR and TOPSIS. Eur. J. Oper. Res. 2004, 156, 445-455. [CrossRef]

(C) 2018 by the authors. Licensee MDPI, Basel, Switzerland. This article is an open access article distributed under the terms and conditions of the Creative Commons Attribution (CC BY) license (http://creativecommons.org/licenses/by/4.0/). 